\title{
Lexicography and Language Planning in 18th Century Sweden*
}

\author{
Lena Rogström, Department of Swedish, University of Gothenburg, \\ Sweden (lena.rogstroem@svenska.gu.se)
}

\begin{abstract}
The 18th century was important for Swedish linguistic development. Foreign lexical influence and orthographical standardization were intensely discussed, and the vocabulary was codified in several dictionaries, all bilingual. In this article, two questions of 18th century lexicography are studied in two influential dictionaries: Serenius (1741) and Sahlstedt (1773). The first question concerns the inclusion of Latin and Swedish legal lexical items in the lemma list; the second question examines the lexicographical treatment of the lexical item and the division into senses.

40 lexical items with a legal sense were extracted from the first two judicial handbooks written in Swedish (Rålamb 1674 and Kloot 1676). As a benchmark, Dalin (1850-55) was used; a monolingual dictionary representing the period when lexicography became fully developed in Sweden. Two modern dictionaries are also used as a comparison, SO (2009) and NSEOP (2018). The results indicate that both Serenius and Sahlstedt were loyal to the ideas of their time. They included only Latin lexical items that were already fully incorporated in Swedish and relevant for general dictionaries. The judicial senses are also discerned in the articles, but sense indicators are used in an inconsistent way and examples get mixed up. The lexicographers also lean heavily on Latin as meta language.
\end{abstract}

Keywords: 18TH CENTURY, SWEDEN, BILINGUAL LEXICOGRAPHY, LEGAL LEXICAL ITEMS, SERENIUS, SAHLSTEDT, LEXICOGRAPHICAL DEVELOPMENT, LANGUAGE PLANNING, LATIN, SWEDISH

Opsomming: Leksikografie en taalbeplanning in 18de-eeuse Sweeds. Die 18de eeu was 'n belangrike tydperk vir Sweedse taalkundige ontwikkeling. Vreemde leksikale invloed en ortografiese standaardisering is in erns bespreek, en die woordeskat is in verskeie woordeboeke, almal tweetalig, gekodifiseer. In hierdie artikel word twee vraagstukke van die 18deeeuse leksikografie in twee invloedryke woordeboeke bestudeer: Serenius (1741) en Sahlstedt (1773). Die eerste vraagstuk hou verband met die insluiting van Latynse en Sweedse leksikale regsitems in die lemmalys; die tweede vraagstuk hou verband met die leksikografiese hantering van die leksikale item en die verdeling daarvan in betekenisse.

40 leksikale items met 'n regsbetekenis is onttrek uit die eerste twee regshandboeke wat in Sweeds geskryf is (Rålamb 1674 en Kloot 1676). Dalin (1850-55), 'n eentalige woordeboek wat verteenwoordigend is van die tydperk waarin die leksikografie ten volle in Swede ontwikkel is, is as maatstaf gebruik. Twee moderne woordeboeke, SO (2009) en NSEOP (2018), word ook ter vergely-

* Thanks to Anna Hannesdóttir, Rhonwen Bowen, and the two anonymous reviewers for many valuable comments. 
king gebruik. Die resultate dui daarop dat beide Serenius en Sahlstedt getrou aan die opvattings van hul tyd was. Hulle het slegs Latynse leksikale items wat reeds ten volle in Sweeds geïnkorporeer is en wat belangrik vir algemene woordeboeke was, ingesluit. Die regsbetekenisse is ook in die artikels onderskei, maar betekenisaanduiders is inkonsekwent gebruik en voorbeelde is deurmekaar aangegee. Die leksikograwe het ook sterk op Latyn as metataal gesteun.

Sleutelwoorde: 18DE EEU, SWEDE, TWEETALIGE LEKSIKOGRAFIE, LEKSIKALE REGSITEMS, SERENIUS, SAHLSTEDT, LEKSIKOGRAFIESE ONTWIKKELING, TAALBEPLANNING, LATYN, SWEEDS

\section{Introduction and aims}

Dictionaries play an important role in the process of language planning and have probably done so for as long as lexicography has existed (Nkomo 2018: 152; cf. Bergenholtz and Gouws 2006). Dictionaries provide a systematic framework for the description and codification of the vocabulary and they are often perceived and used as a linguistic standard for orthography and morphology. Since the most salient feature of dictionaries is the words and their semantic descriptions, the choice of headwords can function as a tool for language planning strategies. Today, Swedish dictionaries do not have an explicit function of being prescriptive regarding the vocabulary, but the general public still consider dictionaries to be normative (Josephson 2018: 180ff.). Traditionally, dictionaries are usually seen as representatives of a lexical norm; they still bring about emotional discussions on lexical change, which indicates their delicate function in the process of language cultivation.

In modern Swedish language planning, dictionaries and glossaries have a natural place in the continuous work of corpus planning. This function can be traced back to the 18th century, a significant period for Swedish lexicography when discussions on linguistic standardization were widespread and Swedish vocabulary was subject to a great expansion. One part of this important process was to replace Latin with Swedish in order to consolidate the Swedish vernacular as a useful tool, thus helping to increase and elaborate science and education in the considerably diminished kingdom of Sweden after a long period of devastating wars that ended with the death of king Charles XII in 1718. His death put an end to the era of the Great Power of Sweden and the final loss of the territories surrounding the Baltic Sea (cf. Teleman 2002). The domains of the natural sciences (with the biologist Carl Linnæus as the fix star) and the judicial domain in which a new national code of law was about to be published, were of particular interest for lexical development.

The overall aim of the study presented is to clarify how this lexical discussion is reflected in 18th century lexicography, thereby creating more knowledge about which role dictionaries played in early language planning in Sweden. Two research questions can be identified. The first question concerns the inclusion of Latin and Swedish legal lexical items in the lemma list, the second 
question regards the lexicographical treatment of the lexical item and whether the judicial meaning could be clearly discerned in the division into senses (I use the simplified designations Swedish and Latin for lexical items of Germanic and Latin/Greek origin respectively.). The study focuses on the treatment of legal lexical items in two dictionaries, Serenius (1741) and Sahlstedt (1773), that both played an important role in the establishment of Swedish lexicography. As a benchmark, Dalin's dictionary from 1850-55 is used; a period when lexicography was fully developed in Sweden. A comparison to contemporary dictionaries is also made. The purpose of this study is mainly related to the role the dictionaries might have played in the strategic question of how Swedish vernacular should be strengthened by the removal of foreign (i.e. Latin) loanwords. As a consequence of this, certain lexicographic questions were brought to the forefront, above all, the question of which lexical items for specific purposes to include in a general dictionary, and how to explain their specific sense in the lexicographic structure during a period when Swedish lexicography was still finding its way.

The study consists of six sections. In section two, a brief view of research on the history of Swedish lexicography and Swedish language planning during the 18th century is presented. In section three, the difference between lexicography and terminography is discussed and some notational use is explained. Section four contains the description of the material used in the study, and section five encompasses the results of the study. Finally, section six gives a short conclusion of the results.

\section{An overview of Swedish lexicography and language planning during the 18th century}

The emergence and establishment of Swedish lexicography is very well mapped out (cf. Hannesdóttir 1998, Hannesdóttir and Ralph 1988, Holm and Jonsson 1991, Holmer 2016, Johansson 1997, Larsson 2003, Malmgren 1988, Norén 1991, Ralph 2012, Rogström 1998). The development of Swedish vocabulary from 1800 and onwards is thoroughly treated in the ORDAT project (Malmgren 2000). Other research on Scandinavian lexicography from a historical point of view is presented by Jacoby (1990), Haugen (1984) and Malmgren and Sköldberg (2013). Tiisala (2018) describes the paratextual context of Serenius's English-Swedish-Latin dictionary from 1734, thereby introducing a new perspective on historical lexicography, which focuses on the context of dictionary making. This perspective elucidates the role of the dictionary in a cultural context. Studies such as Tiisala's can also tell us more about the lexicographer's view of codification and normative questions.

The roots of Swedish lexicography can be traced back to the 14th century, but its most profound development took place during the 18th century when lexicographers actively took part in the language planning process and bilingual lexicography set the foundations for linguistic standardization (cf. Han- 
nesdóttir 1998, 2000, 2011; Rogström 1998, 2010, 2017). Haugen (1985) gives a brief description of how certain important Scandinavian dictionaries have contributed to the standardization of the vernaculars of the Scandinavian languages, relating to one of the basic processes in his model for language planning, i.e. the process of codification (Haugen 1987). This model is also used by Hannesdóttir (2000) and Rogström (2010, 2017) and functions as a basic theoretical onset also for the study at hand.

Teleman $(2002,2003,2005)$ gives a detailed overview and analysis of the standardization of Swedish starting with the 17th century, and, like Haugen (1985), he also allots Swedish lexicographers an important role in creating the stance for a more systematic treatment of Swedish orthography and morphology. Teleman also emphasizes the increased possibilities of lexical choices that were offered by the newly coined Swedish equivalents to foreign headwords in bilingual dictionaries (2002: 59).

During the late 17th century, Sweden held a position in Europe as a strong and important country with provinces around the Baltic Sea. The geographical situation made the nation multilingual, with vernaculars like Finnish, German, Estonian, Latvian and Russian (Teleman 2002: 24). In order to reflect the glory of this vast nation, Swedish had to be strengthened and cultivated. During the 18th century, Swedish was the dominating language of the official administration but Latin was unthreatened in certain domains such as the fine arts, science, jurisprudence and higher education. Since Sweden confessed to the Protestant church, vernaculars were used in church and for religious practice (Teleman 2002: 25). The status of Latin and foreign lexical influence on the vernaculars was profoundly discussed in Sweden as well as in the rest of Europe, and in the late 17th and early 18th centuries, the position of Latin started to give way to Swedish, and the choice between the two languages in technical domains was not obvious any longer (cf. Gunnarsson 2011). In the legal domain, discussions on the use of Latin had started already in the 17th century. Legislation and legal processes had always been conducted in the vernacular whereas Latin was used for legal education and jurisprudence. In 1614, an important reform was carried out in the Swedish legal system when the Courts of Appeal were inaugurated, overtaking the role of the highest instance of appeal that, up until then, had been performed by the King. The new situation created a need for more professional lawyers and judges also in the lower courts (Korpiola 2014: 30; Modéer 2014: 402ff.), and the system for legal education was slowly improved. In 1674 and 1676, the first two legal handbooks in Swedish were published, which was perhaps as a response to the need for better legal education (Rogström and Landqvist 2018a, b). Not only were the changing conditions of the judicial system of vital importance for the improvement of judicial education; the reformation of the judicial system also had a certain linguistic impact. In 1686, King Charles XI appointed a committee to compile a common law for the whole country; this process was not completed until 1736 when a new Swedish code of law was ratified by the Swedish parliament. One of the guiding princi- 
ples for the work of the committee was to avoid foreign loanwords, especially Latin ones (Westman 1912: 61). The new code of law turned out to be a linguistic role model already from the start (Teleman 2002: 79) and became important for the standardization of Swedish. A more comprehensive description of the linguistic efforts of the King's Law Committee of 1686 is given in Rogström (2009).

Law and language are closely connected. This is one reason for choosing legal language as material for the study at hand. Another reason is that legal vocabulary stands out in contrast to many other technical vocabularies and shares many similarities with general language. Legal language is rooted in national culture and used by laymen in a way that many other technical languages are not (Mattila 2013), which makes it interesting to analyse from a lexicographical point of view. Hoare (2009: 85) characterizes Law as a subject "of exceptional lexicographic interest $[\ldots] "$ and discusses the need to include both Latin terms and their vernacular equivalents in legal dictionaries. One reason for this is the two different kinds of targeted readers: the professional and the layman (2009: 86). Since judicial language is often used by ordinary target users in their daily lives, legal vocabulary could be expected to be a part of the lemma list of general dictionaries as well, as Svensén (2009: 71f.). points out. Nowadays, most people encounter legal matters at various points during their lifetime and there is no reason to believe that this was not the case also in the 18th century. From that perspective, the argument for including legal lexical items in 18th century general dictionaries would be the same as for modern lexicography although access to dictionaries was more scarce for the 18th century user than is the case today. Nielsen (2015) argues that the relationship between legal language and lexicography needs to be clarified in greater detail for modern lexicography, and according to the judicial and linguistic situation in 18 th century Sweden, such a study seems to be important for that period as well.

\section{Lexicography and terminography}

Legal vocabulary is not a product of systematic terminological work as many other technical vocabularies are (Mattila 2013: 137ff.), and its connections to general vocabulary as well as to language for specific purposes make it interesting from a lexicographical point of view. Therefore, general vocabulary is usually treated in dictionaries whereas terminology is usually treated by terminologists in the area of terminography. Dictionaries of general language are expected to include frequently used technical terms, whereas dictionaries of language for specific purposes (LSP) hardly ever include any general words (Svensén 2009: 3, Vrbinc and Vrbinc 2013: 440). For a more detailed discussion on scientific and technical dictionaries, see Becker (2015). The dichotomy between lexicography and terminography has different theoretical onsets but in recent years a certain rapprochement is discerned between the two disciplines (Bowker 2018, Faber 2012, Fontenelle 2014, Geeraerts 2015). Today, more 
technical terms tend to be included in dictionaries of language for general purposes, LGP-dictionaries, thus changing the boundaries between dictionaries of LGP and LSP. One explanation for this might be that technical language concerns the target user to a greater extent nowadays. When more and more people get highly dependent on technology, the need for technical vocabulary increases (cf. Vrbinc and Vrbinc 2013).

During the 18th century, however, neither of the disciplines of lexicography and terminography was clearly recognized as belonging to different theoretical onsets. Although Linnæus organized the naming of botanical items in a binominal conceptual system during the 18th century, theoretical discussions of terminology were not common until the end of the 19th century, following the rapid growth of electricity (Laurén et al. 1997: 16f); consequently, there is no reason to believe that 18th century lexicographers made a difference between terms and words. Therefore, I have chosen to use the designation lexical item in this study, since it might cover single lexical items as well as multi-word units regardless of their terminological status. Swedish and Latin lexical examples are written in italics, domare, judex, and the English translation in brackets and a single apostrophe ['judge']. The semantic meaning of a lexical item is used with straight apostrophes: 'judge'. Lexicographical examples are written in smaller typography.

\section{Material}

In this section the material of the study is presented. In subsection 4.1 the lexical sample is described and in subsection 4.2 the dictionaries are presented in chronological order.

\subsection{The lexical items}

This study seeks to establish which legal vocabulary was included in two important dictionaries, by Serenius and Sahlstedt respectively, from the 18th century when bilingual lexicography became important for linguistic standardization in Sweden (Hannesdóttir 2000). In order to find an appropriate sample of such lexical items, I have taken central legal lexical items from the first two legal handbooks in Swedish, by Rålamb (1674) and Kloot (1676). The lexical items were originally extracted by Rogström and Landqvist (2015, 2018a, b) and used in their studies on Rålamb's and Kloot's use of Latin and Swedish. All the lexical items in their sample originate from the authors' chapters on the Civil Procedural Law. Rålamb and Kloot treat the same content, i.e. legal processes, and both books were written for educational purposes. The handbooks most probably were used in the lower courts, thus being tools for the growing professionalization of Swedish judges and lawyers. There is no evidence of the two authors being aware of each other's books (Björne 1995: 36). 
For the study at hand, a total of 40 lexical items were used, and the ones that were omitted from the original sample were mostly long phrases, probably originating from Latin structure. One such example is the phrase: "processens begynnelse igenom saksens inför rättens föreställande" ['The opening of the process by presenting the case to the court'] [my translation]. The Latin expression is: Litis Contestatio.

In the handbooks, many of the lexical items are used synonymously in Swedish and Latin, i.e. appellera/vädja ['to appeal']; domare/judex ['judge']; kärande/ actor ['plaintiff']. A few of the Latin lexical items could be called true Latin (i.e. judex) since they are used in their Latin spelling and form, whereas other Latin lexical items have been adjusted to Swedish spelling and morphology (i.e. citera), hence called adjusted Latin. By studying which legal lexical items from the handbooks are included in Serenius's and Sahlstedt's dictionaries and the way they were described, conclusions can be drawn about how lexicographers understood the lexical items according to their general and/or technical status, and to what extent the Latin lexical items were included in relation to the Swedish ones (cf. Teleman 2002: 59).

In order to make sure that the lexical items from the handbooks were used also in other contemporary legal contexts, the protocols of the King's Law Committee of 1686, (edited by Sjögren 1900-1909), have been used for comparison. In the protocols, both general vocabulary as well as legal lexical items are discussed in detail including several of the lexical items chosen for this study. Many of the same lexical items were included in the draft of the code of law (Rogström 2010). This enhances their chances of being included in a dictionary, since it could be assumed that they would be of general interest. The sample is made up of the following 40 lexical items (written in modern spelling):

Table 1: The sample of lexical items used in the study

\begin{tabular}{|l|l|}
\hline Lexical items & Translation \\
\hline actor & plaintiff \\
\hline appellera & to appeal \\
\hline bilägga & to settle (a dispute) \\
\hline citation & writ of summons \\
\hline citans & plaintiff \\
\hline citatus & defendant \\
\hline citera & to summons \\
\hline contumacia & insubordination \\
\hline dilation & postponement \\
\hline
\end{tabular}




\begin{tabular}{|c|c|}
\hline dom & verdict \\
\hline domare & judge \\
\hline domsaga & judicial district \\
\hline döma & to judge \\
\hline execution (effektuera) & to execute (effectuate) \\
\hline frikänna & to acquit \\
\hline fälla & to pass (a sentence) \\
\hline förlikning & reconciliation \\
\hline judex & judge \\
\hline jäva & take exception to \\
\hline kärande & plaintiff \\
\hline lagsöka & to summons \\
\hline ogilla & to disallow, reject \\
\hline olydnad & insubordination \\
\hline part & party \\
\hline process & lawsuit \\
\hline rannsaka & to cross-examine \\
\hline rekvisit & requisites \\
\hline resolution & resolution \\
\hline rätt & court \\
\hline rättegång & trial \\
\hline sak & case \\
\hline sakförare & lawyer \\
\hline stämma & to summons \\
\hline stämning & writ of summons \\
\hline svara för rätta & to answer in court \\
\hline svarande & defendant \\
\hline tredska & insubordination \\
\hline uppskov & postponement \\
\hline vädja & to appeal \\
\hline åklagare & prosecutor \\
\hline
\end{tabular}




\subsection{The dictionaries}

There are three dictionaries used in this study, two of which were compiled in the 18th century and represent the central part of the study: Serenius (1741) and Sahlstedt (1773). A third dictionary, Dalin (1850-55), represents the period when Swedish lexicography became fully developed. Two modern dictionaries are also used for comparisons, SO (Svensk ordbok) (2009) and NSEOP (Norstedts svensk-engelska ordbok (professionell)) (2018) (See section 4.2.1. for a detailed description of the dictionaries.). The dictionaries were chosen according to three parameters: good lexicographical quality, an expectation that they would reflect the contemporary vocabulary of their time, and, finally, they would represent two different lexicographical typologies, monolingual and bilingual dictionaries. Thus, the dictionaries represent both the pioneer era of Swedish lexicography and the fully developed stage of the 1850's and onwards. This also means that the dictionaries could be subject to different lexicographical techniques in their descriptions of technical language.

\subsubsection{The 18th century dictionaries: Serenius (1741) and Sahlstedt (1773)}

Serenius's Dictionarium Suethico-Anglo-Latinum (1741) is the first dictionary of Swedish and English. In 1734, Serenius published an English-Swedish dictionary that he later turned into a Swedish-English one by selecting a smaller range of lemmas adjusted to the new function of the dictionary (see Rogström 1998 for a detailed description). The dictionary explains the Swedish lemmas in both English and (often, but not always) Latin, but the main languages are Swedish and English and the structure is clearly bilingual. It comprises 8,133 lemmas (Rogström 1998). The dictionary is the first Swedish dictionary to give information of the parts of speech for every headword and for most derivatives.

The preface explains that the dictionary was compiled with the purpose of facilitating trade between England and Sweden. Subsequently, the vocabulary encompasses many lexical items that are central for tradesmen (Rogström 1998). The intended target users are native speakers (hence L1-speakers) of Swedish who need to communicate in English. Since the dictionary includes a section with rules of English pronunciation (Olofsson 1991), the dictionary was most probably intended as a resource also for spoken English. The dictionary is thereby a bilingual dictionary for active use for L1-speakers of Swedish (Svensén 2009: 15). The dictionary has no information of how the articles are structured. Since the target users were expected to know Swedish, explanations of different senses and information concerning stylistic register of the Swedish headwords need not be given in detail. On the other hand, more extensive information is needed for the target language, English, in order for the user to be able to choose the right equivalent (Svensén 2009: 15). A certain kind of symbol is used as sense indicator, a small hand with a pointing index finger ( 
known as manicule or printer's fist.

There is reason to believe that Serenius was interested in linguistic standardization. He dedicates the dictionary to the Swedish parliament, hoping that one day the members of the parliament will use their power to bring some order into the standardization of the Swedish language. Rogström (1994) has also shown that Serenius made use of the orthographical rules that were promoted by the Royal Swedish Academy of Science, who also sponsored the edition of Sahlstedt's dictionary, and in their early days had a pronounced interest in Swedish language planning (Teleman 2002: 69ff.)

Sahlstedt's Svensk ordbok ['Swedish Dictionary'] (1773) comprises approximately 21,500 lemmas (Hannesdóttir 1998: 106f.). Sahlstedt's dictionary was very influential in its day. His main purpose was to improve the principles for orthography and morphology for Swedish, and he was the first lexicographer to present a system of declinations for the nouns, based on gender and plural endings. Sahlstedt's dictionary is a bilingual Swedish-Latin dictionary, but Sahlstedt never had the intention of writing a dictionary that could be used for production in Latin. Instead, his dictionary aimed at explaining Swedish vocabulary using Latin. Consequently, the form of the target language differs somewhat between equivalents and more explanatory phrases. Sahlstedt put some effort into describing on what grounds he had compiled his dictionary. He explains his choice of headwords, and he discusses the importance of an orthographic standard; this is a very relevant factor for both lexicographical compilation as well as standardization on a larger scale. He does not explicitly mention which target users he has in mind, but he states that dictionaries are important both for foreigners who strive to learn a foreign language, as well as for natives to learn the correct usage of words (Sahlstedt, preface p. 2).

Sahlstedt obviously aims at a broad target-user group consisting of learners as well as L1-speakers of Swedish, and with that approach, his dictionary could be considered as bi-functional rather than bi-directional (cf. Hannesdóttir 2014). The problem of a foreign learner understanding the Swedish source language is solved with the use of a Latin index where the Latin equivalents to the Swedish lemmas are used as the source language. Hence, the index functions as an inverted entry list to the main part of the dictionary. However, the learners would most probably have to know some Swedish in order to use the index successfully, since many declinations and compounds are placed in the article of the headword - important information that is lacking in the index.

In his foreword (p. 6), Sahlstedt discusses LSP in conjunction with the lexical material he has included in his dictionary: "Books on Theology and Law use special words, and a certain way of writing. I have only included those words that are used in general language or in books that treat such subjects. They are marked with a special sign." [My translation.] At the end of the preface (p. 16), Sahlstedt lists the abbreviations that he uses in the dictionary: "V. jur. term. jur. Vox juridica. Terminus juridicus. Words or sayings that are used in the court." [My translation.] 
Sahlstedt compiled his dictionary on commission from the Royal Swedish Academy of Sciences that also had supported his grammar, published in 1769, to accompany his dictionary. The two books have played an important role in the codification of Swedish grammar and orthography. Sahlstedt could not have been aware of the impact his books would have on linguistic standardization, but he was well aware of the advantage of combining a grammar and a dictionary to exemplify linguistic use of certain lexical items and constructions (Sahlstedt 1773, preface, p. 9).

\subsubsection{The 19th century dictionary: Dalin (1850-55)}

Dalin's Ordbok öfver svenska språket ['Dictionary of Swedish'] (1850-55), could be said to be the representative of the fully established Swedish lexicographical development, since it was the first complete monolingual defining dictionary of Swedish. It comprises 60,000 lemmas (Malmgren 1988: 201) and it held the position of being the standard Swedish dictionary for nearly a century. Dalin's dictionary was first described in detail in Norén (1991) and later in Hannesdóttir (1998). Even compared to modern lexicography, Dalin's dictionary shows a high standard, especially considering the semantic description with senses and subsenses (Malmgren 1988: 205). The articles are structured with separate numeric sense indicators, and the preface gives comprehensive information concerning both the structure and intended usage of the dictionary. Dalin makes use of approximately 60 diasystematic labels, listed in the preface. One of the labels is Lagt., short for Lagterm ['Law term']. Dalin has no information, however, of how the subject fields should be understood or what the difference is between a word and a term.

\subsubsection{The modern dictionaries: SO (2009) and NSEOP (2018)}

Two modern dictionaries are used as comparative material, in order to see which legal lexical items in the study are still in use. The monolingual dictionary is Svensk ordbok utgiven av Svenska Akademien (SO) ['The Contemporary Dictionary of the Swedish Academy'] (2009). This is the contemporary, standard, defining dictionary in Swedish, available both in print and on the Internet (www.svenska.se). It comprises 65,000 headwords and the intended target users are speakers of Swedish and learners at an advanced level. The dictionary is suitable for both passive and active use, i.e. for both understanding and producing Swedish.

The modern bilingual dictionary is Norstedts svensk-engelska ordbok, Professionell (NSEOP) ['Norstedt's Swedish-English Dictionary, Professional']. The printed edition was published in 2010 and the electronic, somewhat enlarged edition, was released in 2018. The electronic edition comprises approx. 87,000 headwords and 53,000 phrases. NSEOP (2018) can be categorized as an active dic- 
tionary for L1-speakers of Swedish (cf. Svensén 2009: 15). The preface in the printed dictionary (2010) gives a brief description of how the dictionary is structured in order to give the user the best opportunities to choose the right equivalent, but the digital version used for the present study has no such information.

\section{Results}

In this section, the results of the study are presented. In section 5.1, the representation of the lexical items in the dictionaries is presented and discussed, followed by section, 5.2. in which the results from the lexicographic study are presented. Finally, a summary of the results is given in section 5.3.

\subsection{Lexical representation in dictionaries}

The first of the research questions set out for this study concerns the choice between Latin and Swedish legal lexical items in the dictionaries. In relation to this question, the 18th century dictionaries are of special interest. One assumption is that an overlap between the vocabulary in the legal handbooks and the older dictionaries reveals something of the stance of the dictionaries in the process of lexication (Haugen 1987), where one strategy practised was to replace Latin legal lexical items with Swedish. By tracking the sample of 40 lexical items over time, it is possible to get a notion of how the lexical items were represented in early Swedish lexicography and how the legal character of the lexical items was expressed with regard to the typology of each dictionary.

The results are presented in alphabetical order in Table 2. ("X" in the table means that the actual lexical item is included in the dictionary with a legal sense. "- means that the lexical item is not included in the dictionary. "Not legal" means that the lexical item is included but lacking a clear legal sense, and "index" means that the lexical item is placed in the Latin index.) Some lexical items function as sublemmas instead of headwords, and in those cases the headword of the article is given. A few of the lexical items have been considered equals to the lexical items in the sample, although they have a different form. All lexical items are written using modern spelling.

Table 2: Lexical representation in the dictionaries by Serenius (1741), Sahlstedt (1773), and Dalin (1850-55)

\begin{tabular}{|l|l|l|l|}
\hline Lemma & Serenius (1741) & Sahlstedt (1773) & Dalin (1850-55) \\
\hline actor & - & $\mathrm{X}($ index: actor $)$ & $\mathrm{X}($ aktor $)$ \\
\hline appellera & - & - & $\mathrm{X}$ \\
\hline bilägga & $\mathrm{X}$ & $\mathrm{X}$ & $\mathrm{X}$ \\
\hline
\end{tabular}




\begin{tabular}{|c|c|c|c|}
\hline citans & - & - & - \\
\hline citation & - & - & $\mathrm{X}$ (not judicial) \\
\hline citatus & - & - & - \\
\hline citera & $x$ & $x$ & $\mathrm{X}$ (not judicial) \\
\hline contumacia & $\mathrm{X}$ & $\mathrm{X}$ (index: contumax) & $\mathrm{x}$ \\
\hline dilation & - & $\mathrm{X}$ (index: dilatio) & $x$ \\
\hline dom & $x$ & $x$ & $x$ \\
\hline domare & $x$ & $x$ & $x$ \\
\hline domsaga & - & $\mathrm{x}$ & $x$ \\
\hline döma & $x$ & $x$ & $x$ \\
\hline execution & X (in EXECUTORIAL) & - & $x$ \\
\hline frikänna & - & $x$ & $x$ \\
\hline fälla & $x$ & $x$ & $x$ \\
\hline förlikning & X (in FÖRLIKA) & $x$ & $x$ \\
\hline judex & - & $\mathrm{X}$ (index: judex) & - \\
\hline jäva & $\mathrm{X}$ & $\mathrm{x}$ & $x$ \\
\hline kärande & X (in KÄRA til en) & X (in KÄRA) & $x$ \\
\hline lagsöka & X (lagsökning, in LAG) & $x$ & $x$ \\
\hline ogilla & $x$ & $x$ & $x$ \\
\hline olydnad & $X$ (in OLYDIG) & $x$ & $\mathrm{X}($ not judicial $)$ \\
\hline part & $x$ & $x$ & $x$ \\
\hline process & $\mathrm{x}$ & $x$ & $x$ \\
\hline rannsaka & $x$ & $x$ & $X$ \\
\hline rekvisit & - & - & $x$ \\
\hline resolution & - & - & $x$ \\
\hline rätt & $x$ & $x$ & $x$ \\
\hline rättegång & $x$ & $x$ & $x$ \\
\hline sak & $x$ & $x$ & $x$ \\
\hline sakförare & - & - & $x$ \\
\hline stämma (vb) & $x$ & $x$ & $x$ \\
\hline stämning & $x$ & $x$ & $x$ \\
\hline svara för rätta & X (svaranden för rätta, in SVARA) & X (in SVARA) & $\mathrm{X}$ (in SVARA) \\
\hline svarande & X (in SVARA) & X (in SVARA) & X (in SVARA) \\
\hline tredska & X (in TRESK) & $x$ & $\mathrm{X}($ not judicial $)$ \\
\hline uppskov & $\mathrm{x}$ & $\mathrm{X}$ & $\mathrm{x}$ \\
\hline vädja & $x$ & $x$ & $x$ \\
\hline åklagare & $x$ & $x$ & $x$ \\
\hline
\end{tabular}


Jacob Serenius, Dictionarium Suethico-Anglo-Latinum (1741)

Serenius's dictionary (1741) lacks twelve lexical items out of 40 (actor, appellera, citation, citans, citatus, dilation, domsaga, frikänna, judex, rekvisit, resolution, and sakförare). Nine of these are of Latin origin and three could be defined as Swedish, i.e. domsaga ('judicial district'), frikänna ('acquit') and sakförare ('lawyer').

Serenius's omission of the Latin lexical items is interesting and might indicate that, by omitting them, he made a deliberate decision (cf. Teleman 2002: 59). Actor, appellera, citation, dilation, rekvisit and resolution were common in legal domains, and their frequent use can be seen in their formal adjustment to Swedish morphology and, in some cases, orthography. Still, Serenius chooses not to include them. Citans, citatus and judex, on the other hand, were probably conceived as true Latin, and no obvious candidates for the Swedish lemma list. However, the Latin lexical items lacking in Serenius's dictionary are represented by corresponding Swedish equivalents, most of them were also included in the sample. The only exceptions are rekvisit and resolution (cf. Table 3). There is no obvious explanation, though, why Serenius has not included the verb frikänna ['acquit'] when he includes its antonym fälla ['pass a sentence']. Domsaga is mostly used in a professional administrative discourse, and Serenius might have considered it less useful in his dictionary. Instead of sakförare ['lawyer'] Serenius uses the (Latin) lexical item advocat, which is still the natural lexical choice in Swedish (with the spelling advokat). (Advocat was also actually used by Rålamb and Kloot, but not in the chapters chosen for this study. The earliest usage is noted in the King Gustaf Vasa's Bible (1541) according to SAOB (the Swedish historical dictionary), and this was, of course, a strong incentive of the usage at the time.)

The comparison between the sample of lexical items extracted from the legal handbooks and their representation in Serenius (1741) shows that Serenius preferred not to include the Latin legal headwords if there were corresponding Swedish equivalents at hand. The result indicates that Serenius could have promoted the strategy of replacing Latin with Swedish lexical items during the 18th century.

\section{Abraham Sahlstedt, Svensk ordbok ['Swedish Dictionary'] (1773)}

Sahlstedt (1773) omits eight lexical items of the sample from the main part of his dictionary; one Swedish (sakförare), and seven Latin (appellera, citation, citans, citatus, execution, rekvisit, resolution). Apart from execution, Sahlstedt omits the same Latin lexical items as Serenius, and just like Serenius, Sahlstedt also prefers advocat to sakförare. One of the Latin lexical items included by Sahlstedt, (citera), shows no clear judicial meaning, since it is only used in the sense of 'to quote'. Sahlstedt uses the Latin index for some of the Latin lexical items: actor, contumacia (in the form contumax), dilatio, and judex. It seems as if Sahlstedt prefers to use Swedish headwords in the main part of the dictionary and Latin lexical items (with Swedish equivalents) in the index. Citation, citans, and citatus are not included at all; one reason for this might be that they are regular word 
formations related to citera, thereby easy to understand anyway by someone who is familiar with Latin.

The two lexicographers' treatment of the Latin lexical items points in the same direction - to promote Swedish headwords if possible - except when lexical items of Latin origin are the most established and (probably) frequently used. Part and process are two more examples of such lexical items. According to SAOB both lexical items have been in use since at least 1540 .

\section{A.F. Dalin, Ordbok öfver svenska språket ['Dictionary of Swedish'] (1850-55)} Just like Sahlstedt, Dalin (1850-55) does not include the lexical items citans, citatus or judex. He is, on the other hand, the first one to include appellera, rekvisit, resolution and sakförare. In the period when Dalin's dictionary was published, several of the lexical items had undergone a semantic change during which the judicial meaning had faded. Besides citation and citera, the lexical items olydnad and tredska (both meaning 'obedience', 'insubordinance') had lost their judicial meaning.

\section{SO (2009); NSEOP (2018)}

It does not come as a surprise that the modern dictionaries also lack the same Latin lexical items as the older dictionaries. SO (2009) lacks six lexical items from the sample (actor, citans, citatus, contumacia, dilation, and judex). The lexical item svara för rätta is represented by a synonymous verb, i.e. stå inför rätta in an example in the article of RÄTT (not SVARA, as in Serenius 1741). There are also some lexical items from the sample that are included in the dictionary but without their earlier, judicial meaning (citation, citera, olydnad, tredska, resolution, and uppskov.).

NSEOP (2018) lacks only four of the 40 lexical items in the sample, all of them true Latin: citans, citatus, contumacia, and judex. Nine lexical items have lost their judicial meaning and are used in a more general sense: actor, bilägga, citation, citera, dilation, execution, olydnad, resolution, and uppskov.

\subsubsection{Summary of results}

Two results can be discerned in this study. The first is that the Swedish equivalents from the sample were preferred to their Latin counterparts. The Latin lexical items included in the main parts of the dictionaries are all adjusted Latin. This means that the lexical items were most likely integrated into general Swedish vocabulary well before the 18th century. Some of them are still used in Swedish legal context (appellera, kontumacie-dom, rekvisit, part, and process). True Latin is avoided altogether, except for four examples, placed in Sahlstedt's Latin index. Although citatus is used in the 17th century Swedish legal handbooks by Rålamb and Kloot respectively in that form, it was probably perceived as true Latin and could not be expected in a dictionary for general purposes. Probably the same could be said about judex, which is listed only in 
Sahlstedt's Latin index. This shows that Sahlstedt did not consider all the lexical items in the sample to be suitable for the general part of the dictionary and that he probably recognized the true Latin forms as part of a more professional, legal context, not relevant for his dictionary. Table 3 gives an overview of the Latin lexical items, their Swedish equivalents and which lexical item is used in each dictionary.

Table 3: Latin lexical items and their representation in all of the dictionaries ( $\mathrm{i}=$ index; $\mathrm{nj}=$ not judicial)

\begin{tabular}{|c|c|c|c|c|c|}
\hline Lexical items & $\begin{array}{l}\text { Serenius } \\
\text { (1741) }\end{array}$ & $\begin{array}{l}\text { Sahlstedt } \\
\text { (1773) }\end{array}$ & $\begin{array}{l}\text { Dalin } \\
(1850-55)\end{array}$ & SO (2009) & NSEOP (2018) \\
\hline $\begin{array}{l}\text { actor; citans; } \\
\text { kärande } \\
\text { (plaintiff) }\end{array}$ & kärande & $\begin{array}{l}\text { actor (i) } \\
\text { kärande }\end{array}$ & $\begin{array}{l}\text { aktor } \\
\text { kärande }\end{array}$ & kärande & $\begin{array}{l}\text { aktor } \\
\text { kärande }\end{array}$ \\
\hline $\begin{array}{l}\text { appellera; vädja } \\
\text { (to appeal) }\end{array}$ & vädja & vädja & $\begin{array}{l}\text { appellera } \\
\text { vädja }\end{array}$ & $\begin{array}{l}\text { appellera } \\
\text { vädja }\end{array}$ & $\begin{array}{l}\text { appellera } \\
\text { vädja }\end{array}$ \\
\hline $\begin{array}{l}\text { citation; stämning } \\
\text { (writ of summons) }\end{array}$ & stämning & stämning & $\begin{array}{l}\text { citation (nj) } \\
\text { stämning }\end{array}$ & $\begin{array}{l}\text { citation (nj) } \\
\text { stämning }\end{array}$ & $\begin{array}{l}\text { citation (nj) } \\
\text { stämning }\end{array}$ \\
\hline $\begin{array}{l}\text { citatus; svarande } \\
\text { (defendant) }\end{array}$ & - & - & - & - & - \\
\hline $\begin{array}{l}\text { citera; lagsöka; } \\
\text { stämma } \\
\text { (to summons) }\end{array}$ & $\begin{array}{l}\text { citera } \\
\text { lagsöka } \\
\text { stämma }\end{array}$ & $\begin{array}{l}\text { citera } \\
\text { lagsöka } \\
\text { stämma }\end{array}$ & $\begin{array}{l}\text { citera (nj) } \\
\text { lagsöka } \\
\text { stämma }\end{array}$ & $\begin{array}{l}\text { citera (nj) } \\
\text { lagsöka } \\
\text { stämma }\end{array}$ & $\begin{array}{l}\text { citera (nj) } \\
\text { lagsöka } \\
\text { stämma }\end{array}$ \\
\hline $\begin{array}{l}\text { contumacia; } \\
\text { olydnad; tredska } \\
\text { (insubordination) }\end{array}$ & $\begin{array}{l}\text { contumax } \\
\text { olydnad } \\
\text { tredska }\end{array}$ & $\begin{array}{l}\text { contumax (i) } \\
\text { olydnad } \\
\text { tredska }\end{array}$ & $\begin{array}{l}\text { contumacia } \\
\text { olydnad (nj) } \\
\text { tredska (nj) }\end{array}$ & $\begin{array}{l}- \\
\text { olydnad (nj) } \\
\text { tredska (nj) }\end{array}$ & $\begin{array}{l}- \\
\text { olydnad (nj) } \\
\text { tredska (nj) }\end{array}$ \\
\hline $\begin{array}{l}\text { dilation; uppskov } \\
\text { (postponement) }\end{array}$ & uppskov & $\begin{array}{l}\text { dilation (i) } \\
\text { uppskov }\end{array}$ & $\begin{array}{l}\text { dilation } \\
\text { uppskov }\end{array}$ & $\begin{array}{l}\text { uppskov (nj) } \\
\text { up }\end{array}$ & uppskov \\
\hline $\begin{array}{l}\text { execution } \\
\text { (effectuation) }\end{array}$ & execution & - & execution & exekution & exekution (nj) \\
\hline $\begin{array}{l}\text { judex; domare } \\
\text { (judge) }\end{array}$ & domare & $\begin{array}{l}\text { judex (i) } \\
\text { domare }\end{array}$ & domare & domare & domare \\
\hline $\begin{array}{l}\text { part } \\
\text { (party) }\end{array}$ & part & part & part & part & part \\
\hline $\begin{array}{l}\text { process; rättegång } \\
\text { (lawsuit, trial) }\end{array}$ & $\begin{array}{l}\text { process } \\
\text { rättegång }\end{array}$ & $\begin{array}{l}\text { process } \\
\text { rättegång }\end{array}$ & $\begin{array}{l}\text { process } \\
\text { rättegång }\end{array}$ & $\begin{array}{l}\text { process } \\
\text { rättegång }\end{array}$ & $\begin{array}{l}\text { process } \\
\text { rättegång }\end{array}$ \\
\hline $\begin{array}{l}\text { rekvisit } \\
\text { (requisites) }\end{array}$ & - & - & rekvisit & rekvisit & rekvisit \\
\hline $\begin{array}{l}\text { resolution } \\
\text { (resolution) }\end{array}$ & - & - & resolution & resolution & resolution \\
\hline
\end{tabular}

The second result is that most of the Swedish lexical items are still in use in legal vocabulary although a few of them have been subject to semantic change due to a process of determinologization (Svensén 2009: 71). These are used in other contexts than the judicial, i.e. actor (now aktör), olydnad, rannsaka, uppskov and tredska. The process of determinologization is starting to show in Dalin's 
dictionary but is most explicit in the contemporary dictionaries (SO 2009 and NSEOP 2018) that still include many of the lexical items from the sample, but without their judicial meaning.

One conclusion that can be drawn from this study is that the coverage of the sample is very good in all the dictionaries and that the lexicographers prefer Swedish headwords to Latin. This strengthens the impression that the 18th century dictionaries are reliable as sources of contemporary, 18th century vocabulary.

\subsection{Lexicographical treatment of the lexical items}

In 18th century Sweden, a vast number of dictionaries were produced, all of them bi- or multilingual, covering all the major European languages. During the 18th century, Swedish lexicography slowly stabilised and the structure of the dictionaries became more and more refined. In the prefaces, Serenius as well as Sahlstedt write about their strenuous labour with the compilation of their dictionaries, but there is no explicit information on the lexicographical structure given by the authors themselves.

The study in this section is based on analyses of the articles that treat the lexical items of the sample. The analyses are illustrated by a detailed description of the article FÄLLA ['to pass a sentence'] from the three oldest dictionaries, thus giving a more detailed glimpse of the establishment of lexicographical structure up until 1850. The choice of FÄLLA is based upon the fact that the word form is homonymous in Swedish and could be either a noun or a verb. The verb is polysemous with four different senses (according to SO 2009). The combination of the homonymous as well as the polysemous aspects of FÄLLA is interesting from a lexicographical point of view and especially the way the judicial meaning is described in the different dictionaries. In addition, the articles of FÄLLA (v) in the older dictionaries all include examples of constructions, phrases and word formation - the treatment of which is interesting to examine from a historical point of view. And - not the least important - the length of the article in each dictionary is manageable for these circumstances.

Jacob Serenius, Dictionarium Suethico-Anglo-Latinum (1741)

The oldest dictionary, Serenius (1741), is a bilingual dictionary aimed at L1speakers of Swedish (see section 3). Out of the 40 lexical items in the sample, Serenius includes 28 , and 20 are used as headwords introducing an article. Six lexical items are found as a sublemma in semantically related articles (see Table 2), each one supplied with information concerning its part of speech, in this case a noun: execution; förlikning; kärande; olydnad; svarande and, tredska.

The verb lagsöka is represented as a nominalization, lagsökning, that could be found in the article of LAG. The phrase svara för rätta ['to answer (in court)'] is represented by its nominal counterpart, svaranden för rätta ['the defendant'], and it is placed in the article of SVARA. 
Serenius usually treats homonyms in separate articles. The senses of the monosemous headwords are explained by English and Latin equivalents and sometimes examples in Swedish and English. Polysemous headwords are explained in the same technique, but also have their different senses separated by the sense indicator ( $\left(\theta^{\circ}\right)$. Serenius does not make use of subject field labels; this is something that Vrbinc and Vrbinc (2013), for example, think should be used in all instances where technical language is treated in bilingual dictionaries.

Since the dictionary is a bilingual one aimed at L1-speakers, the target user is expected to have a good understanding of the semantics of the source language but needs guidance regarding the choice of what corresponding equivalent to choose in the target language. That is probably the reason why Serenius puts very little effort into explaining different senses and stylistic register in the Swedish source language.

The different equivalents are introduced in the beginning of the article in both English and Latin (see picture 1): To Fell, sternere; Fälla (perdere) To drop. Fälla (condemnare) To cast, To condemn. Fälla ned eller kull (subvertere) To give one a fall. The different senses of the verb are marked with sense indicators and the Latin equivalent also helps to separate the different senses.

Picture 1: Article FÄLLA in Serenius (1741)

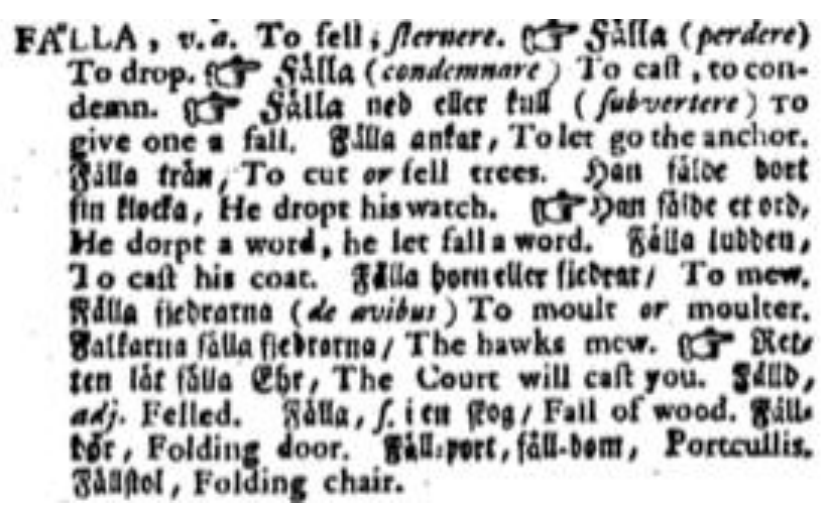

Serenius then gives a selection of examples, sometimes separated by the manicule. One would expect the examples to exemplify the usage of the equivalents, but this is not always the case, since Serenius also illustrates equivalents that are not used earlier in the article. The first example, Fälla ankar, uses an equivalent that is not explained earlier [to let go], and the sentence Han fälde et ord He dorpt [sic] a word, he let fall a word is placed together with examples of how to use the verb To mew or To moult, two other verbs that are not used earlier as equivalents.

It is not altogether clear how the different senses are to be understood in the article. Two Latin equivalents can be identified, condemnere and subvertere, 
each one representing a sense of FÄLLA. The judicial meaning is signalled by a sense indicator but has no equivalent and is only given by the means of a linguistic example in the form of a phrase: Retten lät fälla Ehr, The Court will cast you (written in another tense). The correspondence between the Swedish verb fälla and the English equivalent To cast is the important information in the example, and the user is supposed to understand that this is the judicial sense, since the example treats a legal situation signalled by the noun Retten The court. The English and Latin equivalents (cast and condemnere) of the verb are given already in the beginning of the article. After this linguistic example, Serenius finishes the article by giving the adjective (i.e. past participle) of the verb (Fälld, adj.) and the homonymous noun, placed in the context of a linguistic example (Fälla. s. $i$ en skog / Fall of wood). The article ends with the composites Fäll-dör, Fäll-port, fäll-bom, and Fällstol, which all are compounds to the sense 'to fold'. However, this different sense is not marked with any sense indicator. The noun FÄLLA ['trap'] is also headword in an article of its own, preceding the verb. Of course, the example Fälla. s. i en skog / Fall of wood had been more suitable there.

Although Serenius makes an effort to structure the article logically, he does not succeed completely. A major failing of the structure is that the division into senses is not arranged and described in a systematic way. One explanation for this might be that Serenius had difficulties in handling the material when he turned his English-Swedish dictionary into a Swedish-English one, mixing up some of the senses and categories. It is clear though that Serenius is aware of the importance of distinguishing the different senses, and he tries to do so by using three different techniques: Latin equivalents, manicules and examples. He identifies the judicial meaning of the lexical item, and the examples are relevant.

\begin{abstract}
Abraham Sahlstedt, Svensk ordbok ['Swedish Dictionary'] (1773)
One group of target users of Sahlstedt's dictionary is Swedes who want to learn more about their vernacular, especially orthography and morphology. Another group is foreigners who want to learn Swedish. This is also the reason why Sahlstedt uses Latin as the defining language (preface p. 11, see also Hannesdóttir 1998: 238, 277 and Hannesdóttir 2014: 193ff.). In doing so, Swedish readers with little or no knowledge of Latin could also learn what the Swedish lexical items are in Latin; Sahlstedt especially stresses the technical lexical items (see section 4.2.1) and he explains what subject field labels he uses: $V$. jur. term. jur. Vox juridica. Terminus juridicus. Words or sayings that are used in the court [my translation] (Sahlstedt 1773: 16). The labels are not used in a systematic way, however, and cannot be of much help to the user.

The multiple function of the dictionary would demand more complex information about the Swedish headwords than that which Sahlstedt offers, since a foreign user could not be expected to know which of the Swedish lexical items correspond to the judicial meaning of the Latin equivalent. However, the
\end{abstract}


Latin index helps the user to solve that problem, since the Latin index and the headwords of the main part of the dictionary interact. The Swedish and Latin equivalents often make up the kind of synonyms that are used in the legal handbooks, thus showing that these Latin and Swedish legal lexical items must have been considered to be normal equivalents (or synonyms in a monolingual perspective) (see Table 3).

Out of the 40 lexical items in the sample, 32 are included in Sahlstedt's dictionary, and four of these are found in the index in their Latin form (actor, contumax, dilatio, judex). Kärande is found in the article of KÄRA, and the phrase svara för rätta is found in the article of SVARA, as is the nominalization svarande.

Homonyms are treated in separate articles, and the structure of the articles on a macro level is systematic. The microstructure is sometimes unclear, and it is not always obvious on what grounds Sahlstedt makes his subdivision of the senses. The monosemous articles have no sense indicators but all of the polysemous articles make use of the labels Item. and Aliter. as sense indicators. The semantic relations between the senses are difficult to understand (see Picture 2 with the example of Fälla).

Sahlstedt also uses Latin equivalents, Latin definitions, examples in Swedish and Latin, and word formation, both compounds and derivatives.

Picture 2: Section of article FÄLLA in Sahlstedt (1773)

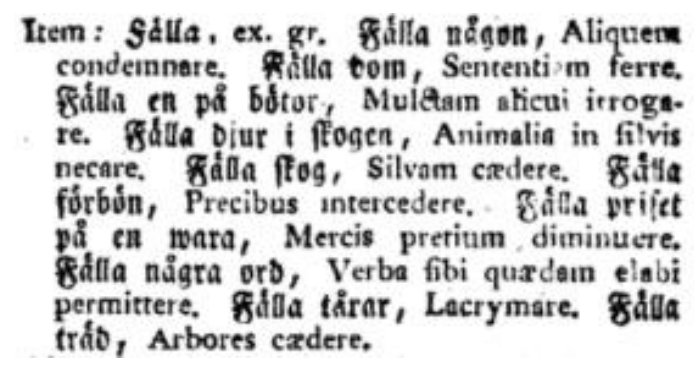

In the example, the special judicial meaning is marked with the Latin label Item. The three first phrases in the section have a judicial sense: Fälla någon ['to convict someone'], Fälla dom ['to pass a sentence'], Fälla en på bötor ['to fine someone']. In Fälla dom the object dom ['verdict', 'sentence'] tells us that the verb should be interpreted as judicial. The same goes for Fälla en på bötor where the object bötor ['fines'] puts the verb in a legal context. For the example Fälla någon, you must know Latin to know that the sense is judicial for this verb.

The rest of the article has examples illustrating other senses of the polysemous verb, but there are no sense indicators that separate the senses. The article is made up from a mixture of several other senses of the verb fälla: Fälla djur $i$ skogen ['to shoot animals in the woods']; Fälla skog ['fell a tree']; Fälla förbön ['offer up prayers']; Fälla priset på en vara ['to cut the price on a piece of 
merchandise']; Fälla några ord ['say some words']; Fälla tårar ['shed tears']; Fälla träd ['fell a tree']. The phrases Fälla skog and Fälla träd illustrate the same sense of the verb: ['to cut down one or several trees']. The Latin equivalent to fälla (cædere) is also the same in both cases, so the only way in which the phrases differ is the way the Latin equivalents to the Swedish lexical items skog ['forest] and träd ['tree'] differ from each other; this is information that might not be altogether relevant in this specific article.

Sahlstedt's relevant two subject field labels ( $v$. jur and term.jur) are used in four of the articles in the sample: åklagare ('prosecutor') (monosemous) and the polysemous lexical items kära ('to accuse'), part ('part'), and svara ('to answer in court'). In the article of PART Sahlstedt also uses another subject field label that is not mentioned in the preface: term. forens. It is not at all clear how he uses the different notations or how he has chosen the lexical items that are labelled. It is important, however, to stress that Sahlstedt's main purpose with his dictionary was to bring more order into Swedish orthography and morphology; a commitment that was successful and resulted in a far more codified norm (Hannesdóttir 2000). Sahlstedt does not discuss semantics at any length in his preface and he probably did not intend to explain the meaning of the lexical items in detail. Still, Sahlstedt's mentioning of two different subject field labels denoting legal lexical items indicates that he was aware of the differences between general and technical lexical items and probably had the ambition of letting it show in his dictionary. However, the article of the verb FÄLLA does not give us any clues as to how Sahlstedt was going to carry out that idea.

A.F. Dalin, Ordbok öfver svenska språket ['Dictionary of Swedish'] (1850-55) Dalin's dictionary is aimed at users with Swedish as their first language. Part of the long article FÄLLA is presented below.

Picture 3: Section of article FÄLLA in Dalin (1850-55)

marken. - 4) (fig.) a) Störta, bringa i forderf.

Sóka (. nảgon. - b) Göra lägre, nedsătu, afslä. $\boldsymbol{F}$. priset pa en vara. $\boldsymbol{F}$. sina ansprük. - $\boldsymbol{c}$ Doma. $F$. till ed, genom laga dom âlagga edgâng. $\boldsymbol{F}$. nảgon till plikt. - d) Döma skyldig. F. en anklagad. Det ar battre alt fria an f., nar den anklagade ej ar fullt ö/cerbevist. e) Förebrin̨a eller innefatta ófverbevisning emot en anklagad, sâ att han kan dômas skyldig. Detta villne, viltnesmäl f-ller den anklagade. - $\cap$ Yura, utsägo, afsaga, afkunna. F, ell ord, elt ullatande, ell yltrande. Han fallde nàgra ord, som blefvo illa upplagna. F. hotelser. F. förböner for nágon. F. dom, utslag. Ilan har fallt sin egen dom, dömt sig sjelf. $\boldsymbol{F}$. omdôme, yttra sitt omdöme, săga sina tankar. $F$. silt omdōme om nảgon, nägot, b/ecr något. - 5 ) (geom.) 
Dalin treats homonyms in different articles. Polysemous headwords have subdivisions. The article of FÄLLA is divided into a total of six senses, each sense marked with a numeral, 1-6. The subsenses are marked with a long hyphen, and identified by small, Latin letters "a-f". Thereby, the subsenses are clearly separated from the main senses. In sense 4 , six different subsenses are listed: (a) = ['bring sb. down']; (b) = ['lower, reduce']; (c) = ['judge']; (d) = ['convict']; (e) = ['Put forward or comprise conviction against the accused, in order to find him guilty']; (f) = ['pass (a word, opinion, verdict)']. The first two subsenses $(a-b)$ are of general nature. The following three senses have a clear judicial meaning (c-e) and the last one, (f), can be used in a general as well as a judicial sense.

All senses are defined with (sometimes very) comprehensive definitions. The senses are exemplified with many phrases, some of which are fixed phrases or collocations: F. omdöme ['to give an opinion']; F. dom, utslag ['to pass a verdict'].

In the beginning of the article, Dalin makes use of the subject field label (fig.), ['figurative, metaphorical'], but he uses no labels to mark the judicial meaning of certain senses in the article. Probably, these are supposed to be explained by the formulation of the definitions. Dalin usually treats nominalizations in separate articles and there are no examples of word formations described in the article of FÄLLA.

Dalin presents a long list of approximately 60 diasystematic labels in his preface (pp. 19-20) but it is quite unclear on what grounds he uses them in the dictionary. Out of Dalin's 30 lexical items from the sample, only three have subject field labels, one of which is contumacia, and the other is jäva. Contumacia is marked with the label (lat.) for 'Latin', while jäva is marked with (Lagt.) for 'law term'. Dalin's use of subject field labels might be unclear but the semantic description has a systematic and consistent structure, although the definitions and examples are very verbose.

\section{Svensk ordbok (2009); NSEOP (2018)}

Both SO (2009) and NSEOP (2018) meet all the requirements of modern dictionaries. In SO (2009), the senses are clearly marked with numerical sense indicators and supported by examples, illustrating constructions, collocations, fixed phrases etc. SO (2009), being a monolingual dictionary, has no reason to include subject field labels since the judicial sense can be understood by the definition. Still, subject field labels are sometimes used, and among the lexical items in this study ogilla is marked with $<$ jur. $>$, maybe because the definition is somewhat insufficient: "inte godkänna" ['not approve of'].

The structure of the articles in the printed edition of NSEOP (2010) is clearly explained in the preface. The lemmas are provided with numeric sense indicators as well as Swedish explanations written in small type. The use of sense indicators is consistent, in accordance with the idea of the dictionary. Subject field labels are used for the "most important words" of different fields that are included, one of which is law, labelled as jur. (short for juridik ['law']). The labels are in Swedish and they are placed directly before the English 
equivalent. There is no information about how to interpret "most important" or where the boundary between general words and terms is drawn.

It appears that most lexical items with judicial meaning are marked with a field label, except when the Swedish headword and English equivalent are both monosemous and have the same meaning, i.e. judicial. One example of this is åklagare ['prosecutor'].

\subsection{Summary of the results}

The lexicographical study shows, as expected, a clear development over time. The oldest dictionary, Serenius (1741), shows an awareness of the target users' needs in terms of isolated senses, usually marked with sense indicators, but the accomplishment of the lexicographical technique does not fully meet the ambitions of the strategy. The number of different senses is hard to discern and the examples and equivalents do not match altogether, which might be a result of a troublesome method when compiling the dictionary. The judicial sense is clearly expressed however and emphasized with several examples. The lexicographical design is focused on the target users' needs, which meets the demands of the typology.

The second oldest Swedish dictionary, Sahlstedt (1773), has definitions in Latin, but a structure that is more similar to a monolingual dictionary than a bilingual. Since the dictionary aims at two quite different groups of target users representing both L1 and L2-speakers, the mission of fulfilling the needs of both groups seems difficult to achieve without a more refined structure. Sahlstedt's main purpose is to try to codify Swedish morphology and orthography, and his dictionary is best used together with his grammar, published in 1769. The structuring of the semantics in the article studied shows many inconsistencies, and it is obvious that the reader must know Latin to fully understand the structure of the article and the senses of the lexical items. This is something of a paradox considering that the description and codification of Swedish were the main purpose of the dictionary. The judicial sense is easy to discern but it is not marked in any special way compared to the other senses.

Dalin's dictionary (1850-55) was published less than one hundred years after Sahlstedt but it reveals a consistent lexicographical structure with detailed semantic descriptions and elaborate definitions. Although Dalin lists judicial sense indicators in his preface, he does not make use of them in the article FÄLLA. Nevertheless, the judicial senses of FÄLLA studied are clearly identified with several examples to support them.

The modern dictionaries (SO 2009 and NSEOP 2018) both show a lexicographical structure in accordance to modern, lexicographical standards.

\section{Final conclusions}

The subject of this article has been to study in what way three influential 18th 
and 19th century dictionaries treat a sample of 40 legal lexical items of Swedish and Latin origin in their dictionaries. In the 18th century, the usage of Latin as opposed to Swedish was intensely discussed, especially in science and the fine arts. At the same time, the period also saw a rapidly growing development of lexicography and the role of lexicography in relation to questions of language planning; this issue is interesting to examine in more detail. A material extracted from the two first legal handbooks in Swedish has been used: the handbooks were published by Rålamb (1674) and Kloot (1676), independently of each other.

The study is based on two specific research questions. The first question concerns the inclusion of Latin and Swedish legal lexical items from the handbooks in the lemma lists of the dictionaries, the second question regards the lexicographical treatment of the lexical items of the sample, especially the division into senses and whether the judicial meaning is clearly recognized or not.

Both Serenius and Sahlstedt, the two 18th century lexicographers, prefer the Swedish equivalents to the Latin, except when the Latin lexical items seem to be already well integrated into Swedish. Their infrequent usage of Latin legal lexical items in the dictionaries seems to be the result of an active decision, since the Latin legal lexical items were probably in use during the whole period examined. One proof of this is their presence in the later dictionaries included in the study, where several of the Latin lexical items are still in use but have been subject to a process of determinologization. Serenius's and Sahlstedt's treatment of the Latin judicial lexical items seems to indicate a strive to reduce the usage of Latin in favour of Swedish, thus trying to follow the direction of Swedish language planning of the time (cf. Teleman 2002: 59, Rogström 2017). They both had an outspoken interest in linguistic standardization, and there is reason to believe that they had an interest in taking active part in the language planning process.

The second research question focuses on the lexicographical treatment of the lexical items in the sample. The study shows that both Serenius and Sahlstedt are aware of the need to structure the article in accordance with the different senses of the headwords, but their lexicographical skills are far from perfect and leave much to be desired. The microstructure of the articles does not follow a set order, and the user cannot rely on the structure of the articles in order to discern the different senses. The most certain way to find a specific piece of lexical information is probably to read the whole article from the beginning to the end. However, in both Serenius's and Sahlstedt's dictionaries, the judicial meaning of the lexical items from the sample are all identified and described through equivalents and illustrated with examples; this indicates that both lexicographers were aware of the importance of separating different senses from each other. Neither of the lexicographers masters the special requirements for bilingual dictionaries, especially not Sahlstedt who is aiming at a bidirectional dictionary for both L1-speakers of Swedish as well as learners.

In Dalin's dictionary (1850-55), the lexicographic development is fully 
established, and his articles are systematically written with clear distinctions between homonyms and related senses of polysemous lexical items within the main sections of the article. The two contemporary dictionaries SO (2009) and NSEOP (2018) are also systematically compiled, and the division into senses clearly identifies the judicial senses that are easy to find and make use of. The only thing still lacking, is the treatment of subject field labels (cf. Vrbinc and Vrbinc 2013). NSEOP (2018) seems to use them in a consistent way, but neither Dalin (1850-55) nor SO (2009) uses their labels in a clear way.

To conclude - the study confirms the assumption that Swedish 18th century dictionaries could be expected to support certain lexical language planning strategies at the time. Both Serenius and Sahlstedt seem to be loyal to the effort of promoting Swedish in favour of Latin during the 18th century. Their selection of headwords indicates a preference for the Swedish vocabulary, and their lexicographical treatment of the chosen headwords also shows an identification of legal lexical items and an awareness of the special requirements needed for the presentation of the judicial meaning of the lexical items. But most importantly, the results show that more detailed studies of the dependence between old dictionaries and early lexical language planning strategies probably could shed more light on a part of Swedish language history that is still waiting to be elucidated.

\section{References}

\section{Dictionaries}

Dalin, A.F. 1850-55. Ordbok öfver svenska språket I-II. Stockholm: Joh. Beckman.

NSEOP = Norstedts svensk-engelska ordbok Professionell. 2010. Stockholm: Norstedts Förlag AB

NSEOP $=$ Norstedts svensk-engelska ordbok Professionell. 2018. Stockholm: Norstedts Förlag AB. <https://www-ne-se.ezproxy.ub.gu.se/ordböcker/\#/search/norstedts-pro-sv-en?q=dunkel>

Sahlstedt, A. 1773. Svensk ordbok. Stockholm: Carl Stolpe.

SAOB = Ordbok över svenska språket, utgiven av Svenska Akademien. 1893-. Lund: Gleerups.

Serenius, J. 1734. Dictionarium Anglo-Svethicum-Latinum. Hamburg: Rudolphum Beneken.

Serenius, J. 1741. Dictionarium Suethico-Anglo-Latinum. Stockholm: Pet. Momma.

$\mathrm{SO}=$ Svensk ordbok utgiven av Svenska Akademien 2009. Stockholm: Svenska Akademien \& Norstedts. $<$ www.svenska.se>

\section{Other literature}

Becker, H. 2015. Scientific and Technical Dictionaries; Coverage of Scientific and Technical Terms in General Dictionaries. Durkin, Ph. 2015. The Oxford Handbook of Lexicography: 393-408. Oxford: Oxford University Press.

Bergenholtz, H. and R.H. Gouws. 2006. How to Do Language Policy with Dictionaries. Lexikos 16: $13-45$. 
Björne, L. 1995. Patrioter och institutionalister. Den nordiska rättsvetenskapens historia. Del I. Tiden före 1815. Rättshistoriskt bibliotek 52. Skrifter utgivna av Institutet för rättshistorisk forskning. Grundat av Gustav och Carin Olin. Serien I. Stockholm/Lund: Institutet för rättshistorisk forskning.

Bowker, L. 2018. Lexicography and Terminology. Fuertes-Olivera, P.A. (Ed.). 2018. The Routledge Handbook of Lexicography: 138-151. London/New York: Routledge.

Faber, P. 2012. A Cognitive Linguistics View of Terminology and Specialized Language. Berlin/Boston: Mouton de Gruyter.

Fontenelle, T. 2014. From Lexicography to Terminology: A Cline, not a Dichotomy. Abel, A., C. Vettori and N. Ralli (Eds). 2014. Proceedings of the XVI EURALEX International Congress: The User in Focus, Bolzano/Bozen, Italy, 15-19 July 2014: 25-45. Bolzano/Bozen: Institute for Specialised Communication and Multilingualism.

Geeraerts, D. 2015. Lexicography and Theories of Lexical Semantics. Durkin, Ph. (Ed.). 2015. The Oxford Handbook of Lexicography: 425-438. Oxford: Oxford University Press.

Gunnarsson, B.-L. (Ed.). 2011. Languages of Science in the Eighteenth Century. Berlin/Boston: Walter de Gruyter.

Hannesdóttir, A.H. 1998. Lexikografihistorisk spegel. Den enspråkiga svenska lexikografins utveckling ur den tvåspråkiga. Meijerbergs arkiv för svensk ordforskning 23. Gothenburg: University of Gothenburg.

Hannesdóttir, A.H. 2000. Tvåspråkig lexikografi och språkplanering i 1700-talets Sverige. Edlund, L.-E. (Ed). 2000. Studier i svensk språkhistoria 5. Förhandlingar vid Femte sammankomsten för svenska språkets historia Umeå 20-22 november 1997: 224-235. Nordsvenska 11. Umeå: University of Umeå.

Hannesdóttir, A.H. 2011. From Vernacular to National Language: Language Planning and the Discourse of Science in Eighteenth-century Sweden. Gunnarsson, B.-L. (Ed.). 2011. Languages of Science in the Eighteenth Century: 107-122. Berlin/Boston: Walter de Gruyter.

Hannesdóttir, A.H. 2014. Lemman och ekvivalenter i nya roller — en reviderad ordbokstypologi. Vatvedt Fjeld, R. and M. Hovednak. (Eds.). 2014. Nordiske studier i leksikografi 12. Rapport fra Konferanse om leksikografi i Norden. Oslo 13.-16 August 2013: 193-211. Oslo: Skrifter utgitt av Nordisk forening for leksikografi.

Hannesdóttir, A. and B. Ralph. 1988. Early Dictionaries in Sweden: Tradition and Influences. Hyldgaard-Jensen, K and A. Zettersten (Eds.). 1988. Symposium on Lexicography IV. Proceedings of the Fourth International Symposium on Lexicography April 20-22, 1988 at the University of Copenhagen. Lexicographica Series Maior 26: 265-279. Tübingen: Niemeyer.

Haugen, E. 1984. A Bibliography of Scandinavian Dictionaries. White Plains NY: Kraus International Publications.

Haugen, E. 1985. Lexicography and Language Planning. Jankowsky, K.R. (Ed.). 1985. Scientific and Humanistic Dimensions of Language. Festschrift for Robert Lado on the Occasion of his 70th Birthday on May 31, 1985: 571-580. Amsterdam: John Benjamins.

Haugen, E. 1987. Blessings of Babel. Bilingualism and Language Planning. Problems and Pleasures. Contributions to the Sociology of Language 46. Berlin/New York/Amsterdam: Mouton de Gruyter.

Hoare, M.R. 2009. Scientific and Technical Dictionaries. Cowie, A.P. (Ed.). 2009. The Oxford History of English Lexicography. Vol. II. Specialized Dictionaries: 47-93. Oxford: Clarendon Press. 
Holm, L. and H. Jonsson. 1991. Swedish Lexicography. Hausmann, F.J, O. Reichmann, H.E. Wiegand and L. Zgusta (Eds.). 1991. Wörterbücher. Dictionaries. Dictionnaires. Ein internationales Handbuch zur Lexikographie. An International Encyclopedia of Lexicography. Encyclopédie internationale de lexicographie. Handbücher zur Sprach- und Kommunikationswissenschaft 5(2): 1933-1943. Berlin/New York: De Gruyter.

Holmer, L. 2016. Grammatik i SAOL. En undersökning av grammatisk information i Svenska Akademiens ordlista över 130 år. Meddelanden från institutionen för svenska språket 65. Institutionen för svenska språket. Gothenburg: University of Gothenburg.

Jacoby, M. 1990. Historische Lexicologie zum nordgermanischen Raum: Lexika als Kultur- und Sprachdokumente zwischen Mittelalter und Neuzeit. Einflüsse von Toledo bis Paris, von London bis Berlin. Wiesbaden: Otto Harrassowitz.

Johansson, M. 1997. Lexicon Lincopense. En studie i lexikografisk tradition och svenskt språk vid 1600talets mitt. Meijerbergs arkiv för svensk ordforskning 21. Gothenburg: University of Gothenburg.

Josephson, O. 2018. Språkpolitik. Språkrådets skrifter 25. Falun: Morfem.

Kloot, C. 1676. Then Swenska Lagfarenheetz Spegel [...]. Gothenburg: Amund Grefwe.

Korpiola, M. 2014. General Background: From Judicial Crisis to Legal Revolution through the Svea Court of Appeal? Korpiola, M. (Ed.). 2014. The Svea Court of Appeal in the Early Modern Period: Historical Reinterpretations and New Perspectives. Rättshistoriska studier 26: 23-54. Stockholm: Institutet för rättshistorisk forskning/Jure.

Larsson, L. 2003. Varifrån kom svenskan? Om den svenska vokabulären i en fyrspråkig ordbok utgiven $i$ Riga 1705. Acta Academia Regiæ Gustavi Adolphi 81. Uppsala: Kungl. Gustav Adolfs Akademien för svensk folkkultur.

Laurén, C., J. Myking and H. Picht. 1997. Terminologi som vetenskapsgren. Lund: Studentlitteratur.

Malmgren, S.-G. 1988. Almqvist, Dalin och den svenska definitionsordbokens födelse. Pettersson, G. (Ed.). 1988. Studier i svensk språkhistoria. Lundastudier i nordisk språkvetenskap A 41: 195-213. Lund: Lund University Press.

Malmgren, S.-G. 2000. Projektet Det svenska ordförrådets utveckling 1800-2000: utgångspunkter. $<$ https://svenska.gu.se/publikationer/ordat>

Malmgren, S.-G. and E. Sköldberg. 2013. The Lexicography of Swedish and Other Scandinavian Languages. International Journal of Lexicography 26(2): 117-134.

Mattila, H.E.S. 2013 [2007]. Comparative Legal Linguistics. Language of Law, Latin and Modern Lingua Francas. Second edition. Farnham, Surrey, UK/Burlington, VT: Ashgate.

Modéer, K.Å. 2014. Mixed Legal Systems in Early Modern Sweden: Judicial Traditions and Reforms in an Expanding European Great Power — Some Concluding Remarks. Korpiola, M. (Ed.). 2014. The Svea Court of Appeal in the Early Modern Period: Historical Reinterpretations and New Perspectives. Rättshistoriska studier 26: 395-422. Stockholm: Institutet för rättshistorisk forskning/Jure.

Nielsen, S. 2015. Legal Terms in General Dictionaries of English: The Civil Procedure Mystery. Lexikos 25: 246-261.

Nkomo, D. 2018. Dictionaries and Language Policy. Fuertes-Olivera, P.A. (Ed.). 2018. The Routledge Handbook of Lexicography: 152-165. London/New York: Routledge.

Norén, K. 1991. Utformningen av artiklarna Dalins Ordbok öfver svenska språket (1850-55). Språk och Stil. Tidskrift för svensk språkforskning. NF 1: 109-138. 
Olofsson, A. 1991. Bilingual Lexicography Swedish-English, English-Swedish. Hausmann, F.J., O. Reichmann, H.E. Wiegand and L. Zgusta (Eds.). 1991. Wörterbücher. Dictionaries. Dictionnaires. Ein internationales Handbuch zur Lexikographie. An International Encyclopedia of Lexicography. Encyclopédie internationale de lexicographie. Handbücher zur Sprach- und Kommunikationswissenschaft 5(2): 3047-3051. Berlin/New York: De Gruyter.

Ralph, B. 2012. Biskopar, ordböcker och verkligheten — vad är lexikografihistoria bra för? Eaker, B., L. Larsson and A. Mattisson (Eds.). 2012. Nordiska studier i lexikografi 11. Rapport från Konferensen om lexikografi i Norden. Lund 24-27 maj 2011: 30-54. Lund: Skrifter utgivna av Nordiska föreningen för lexikografi.

Rogström, L. 1994. Nya tider, nya seder? Om ortografiska principer i Jacob Serenius' ordböcker. Språk och Stil. Tidskrift för svensk språkforskning. NF 4: 65-97.

Rogström, L. 1998. Jacob Serenius lexikografiska insats. Meijerbergs arkiv för svensk ordforskning 22. Gothenburg: University of Gothenburg.

Rogström, L. 2009. Språkplanering i praktiken? En lexikalisk studie i förarbetena till 1734 års lag. Språk och Stil Tidskrift för svensk språkforskning. NF 19: 5-34.

Rogström, L. 2010. I akt och mening. En jämförelse av ordförrådet i 1734 års lag med samtida ordböcker. Reinhammar, M. (Ed.). 2010. Studier i svenska språkets historia 11. Förhandlingar vid Elfte sammankomsten för svenska språkets historia i Uppsala 23-24 april 2010: 189-199. Acta Academiæ Regiæ Gustavi Adolphi 113. Uppsala: Kungl. Gustav Adolfs Akademien för svensk folkkultur.

Rogström, L. 2017 "Om wåra swänske ord komma i bruk, kunna de såwäl som fremmande förstås". En studie av lexikalisk förändring i juridiskt språk på 1600-talet. Språk och Stil. Tidskrift för svensk språkforskning. NF 27: 67-95.

Rogström, L. and H. Landqvist. 2015. Ett tidigt försök att etablera en svensk juridisk vokabulär? Lexikaliska och fackspråkliga perspektiv på en juridisk handbok från 1674. Rellstab, D. and N. Siponkoski (Eds.). 2015. Rajojen dynamiikkaa, Gränsernas dynamik, Borders under Negotiation, Grenzen und ihre Dynamik. VAKKI-symposiumi XXXV. Vaasa 12-13.2.2015: 199-208. VAKKI Publications 4. Vaasa: Vaasan Yliopisto - University of Vaasa.

Rogström, L. and H. Landqvist. 2018a. A Terminologia Latina till Swenska Ord. En studie av latinska och svenska lexikala enheter i två juridiska handböcker från 1670-talet. Lönnroth, H., B. Haagensen, M. Kvist and K. Sandvad West (Eds.). 2018. Studier i svensk språkhistoria 14: 227-243. Vasa: Vaasan Yliopisto - University of Vaasa.

Rogström, L. and H. Landqvist. 2018b. Introducing a Local Legal Vocabulary in a Latin Context. A Study of Two Swedish 17th Century Approaches. Fachsprache. Journal of Professional and Scientific Communication 40(3-4): 161-178.

Rålamb, C. 1674. OBSERVATIONES JURIS PRACTICÆ. Thet är / Åthskillige Påminnelser vthi Rättegångs Saker [...]. Stockholm: Niclas Wankijf.

Sahlstedt, A. 1769. Swensk Grammatika efter det nu för tiden i språket brukliga sättet författad. Uppsala: Johan Edman.

Sjögren, W. 1900-1909. Förarbetena till Sveriges rikes lag 1686-1736. Efter offentligt uppdrag utgifna af Wilhelm Sjögren. Uppsala: Almqvist \& Wiksells boktryckeri-aktiebolag.

Svensén, B. 2009. A Handbook of Lexicography: The Theory and Practice of Dictionary-making. Cambridge: Cambridge University Press.

Teleman, U. 2002. Ära, rikedom och reda. Svensk språkvård och språkpolitik under äldre nyare tid. Skrifter utgivna av Svenska språknämnden 85. Stockholm: Norstedts Ordbok. 
Teleman, U. 2003. Tradis och Funkis. Svensk språkvård och språkpolitik efter 1800. Skrifter utgivna av Svenska språknämnden 87. Stockholm: Norstedts Ordbok.

Teleman, U. 2005. The Role of Language Cultivators and Grammarians for the Nordic Linguistic Development in the 16th, 17th and 18th Centuries. Bandle, O. et al. (Eds.). 2005. The Nordic Languages. An International Handbook of the History of the North Germanic Languages. Volume 2. Handbücher zur Sprach- und Kommunikationswissenschaft 22(2): 1379-1396. Berlin/New York: Mouton de Gruyter.

Tiisala, S. 2018. Subscribers and Patrons: Jacob Serenius and his Dictionarium Anglo-SvethicoLatinum 1734. McConchie, R. and J. Tyrkkö (Eds.). 2018. Historical Dictionaries in their Paratextual Context. Lexicographica. Series Major 153: 237-260. Berlin/Boston: De Gruyter.

Westman, K.G. 1912. De svenska rättskällornas historia: föreläsningar. Uppsala: Appelberg.

Vrbinc, M. and A. Vrbinc. 2013. Differences in the Inclusion and Treatment of Terminology in OALD3, OALD4 and OALD8. Lexikos 23: 440-455. 